liquid. The temperature of the German botion fermentation varies from $5^{\circ} 5 \mathrm{C}$. to $7^{\circ} \mathrm{C}$, a temperature that can only be maintained by the employment of large quantities of ice.

The bottom and top yeasts are probably distinct species. M. Pasteur, however, seems to be in error in stating (p. 190) that the bottom yeast may be distinguished by being less spherical than top yeast. It is true that in London and Edinburgh yeast the cells will be found usually round; hard water, however, such as that at Burton, or artificially made so, yields yeast in which the cells are distinctly ovoid in appearance, resembling very closely Bavarian bottom yeast. M. Pasteur further states (pp. I88 and 192) that the bottom yeast yields a beer of finer flavour, and hence argues the replacement of ales produced by top fermentation by those made on the Bararian system. Here surely he must be thinking rather of the inferior products of the surface fermentation in France and Germany than of those of England and Scotland. His assertions (pp, $12-17$ ) that by bottom fermentation store beers can be produced, whereas those produced by top fermentation must be consumed at once and cannot be transported are certainly strange to an Englishman.

So far from these unfavourable comparisons being true in all cases, the exact opposite is generally the case. Bavarian and other bottom fermentation beers are in fact those which can neither be preserved nor transported without the liberal employment of ice; even that sent from Vienna to London must be kept cold artificially in order to avoid rapid destruction. As regards flavour, there are many who think a glass of Burton pale ale or of good old college rent ale to be supericr to any Bavarian beer. The chief cause of the desline in the production of top fermentation beers on the Continent has been the want of attention in the fermentation process, whereas the English brewer, especially the brewer of high-class ales, has been unremitting in his attention to the tempe. rature in fermentation and to the perfect cleansing of the ale. Now where such attention is given it is not difficult to obtain ales which will keep a few years. While objecting to our English produce being so hastily depreciated by M. Pasteur, our brewers will be the first to avail themselves of his biological researches in order to render their produce more stable and better flavoured, without having recourse to the general adoption of the vastly more costly system of bottom fermentation.

Let us now leave this question of the respective value and future development of the two systems of fermentation, and assume that by either the one process or the other we have obtained our glass of beer. The question now naturally presents itself to us, as to others before us, to what is fermentation due? Pasteur's answer to this I propose to discuss next week.

\section{Charles Graham}

\section{OUR BOOK SHELF}

Manual of the Vertebrates of the Northern United States. By David S. Jordan, M.D. (Chicago: Jansen, McClurg, and Co., I876.)

THIS useful work contains a short diagnostic account of the whole of the vertebrated animals of the Northern United States, and has been written, as the author tells us, to give collectors and students who are not specialists a ready means of identifying the families, genera, and species described. The mammals as well as the birds of North America have been so ably and elaborately treated of by Prof. Baird, Dr. Coues, and others, that those who are studying these branches of zoology will not find this smaller volume of special service, nevertheless we are not acquainted with any work having a range of treatment which includes the reptilia, amphibia, and fishes with the two other classes. The sub-kingdom, as well as each class and order, are concisely defined, and the most modern arrangement is adopted, based upon the best authorities, the relative importance of the characterising features being clearly brought forward. The system of employing artificial keys so useful in botanical determinations, and so successfully employed by $\mathrm{Dr}$. Coues in ornithology, is employed throughout the book, and will, no doubt, be found to work well. A glossary of the principal technical terms used in the body of the book is also appended. As an example of the manner in which the different species are described, we will take that of one of the species of Fly-catchers: "Empidonax acadicus (Gm.), Baird. SMALL GREEN-CRESTED FLY-CATCHER.-Clear olive-green; wing bands buffy; whitish becoming yellowish below ; yellowish ring about eyes ; bill pale below ; primaries nearly an inch longer than secondaries; second, third, and fourth primaries nearly equal, and much longer than first and fifth ; first much longer than sixth ; L. 6 ; W. 3 ; T. $2 \frac{3}{4}$; Ts. $\frac{2}{3}$; Tcl. $\frac{1}{2} ;$ E.U.S. frequent." To naturalists on this side the Atlantic the work will be found a valuable one of reference on account of its inclusiveness, and a glance through it makes us feel how useful a similar one on the British vertebrate fauna would prove to students and collectors.

The Emiorant and Sportsman in Canada. By John J. Rowan. (London: Stanford, 1876.)

THIs is a capital book in many respects. Mr. Rowan is limself an old Canadian settler and knows the country well in various aspects. He tells the plain truth as to the suitability of Canada as a field for emigration, and the intending emigrant could not get a better guide as to the resources of the country, and the kind of settlers for which it is adapted. Mr. Rowan is a keen sportsman and has a fair knowledge of zoology. His descriptions of hunting life in Canada are thoroughly interesting and abound with fresh information on the many animals which are still to be found there. $\mathrm{Mr}$. Rowan is a good observer, and some of the information which he gives regarding the animals with whose habits be is familiar may be new even to naturalists. He describes, at considerable length, especially, the habits of the beaver as observed by himself, and adduces some facts to show that previous popular statements with regard to this animal must be to some extent modified. The volume will be found of interest not only to the emigrant, the sportsman, and the naturalist, but to all who love good hunting and trapping stories well told. Its principal defect is the want of an index.

\section{LETTERS TO THE EDITOR}

[The Eaitor does not hold hininself responsible for opinions expressed by his correspondents. Ncither can he undertake to return, or to correspond with the zeriters of, rejected manuscripts. No notice is taken of anonymous communications.]

On a Mocie of Investigating Storms and Cyclones

I SCARCELY know anything more interesting in connection with the investigation of cyclones and of our storms than the theoretical investigations of Reye, Mohn and Guldberg, and the practical ones of Mr. Clement Ley. Mr. Ley's papers in the Fournal of the Scottish Meteorological Society, iv. 66, I49, 330, have especially attracted my attention. We have to study the 